\title{
Genitourinary Changes in Hamsters Infected and Reinfected with Trypanosoma cruzi
}

\author{
Marlene Cabrine-Santos, Vitorino Modesto dos Santos*, Marcus Aurelho de Lima*, \\ Marta Elena Araújo de Abreu, Eliane Lages-Silva, Luís Eduardo Ramírez ${ }^{+}$
}

\author{
Disciplina de Parasitologia *Departamento de Clínica Médica, Faculdade de Medicina do Triângulo Mineiro, Praça Thomaz \\ Ulhoa 706, 38025-440 Uberaba, MG, Brasil
}

Authors describe genitourinary changes in male hamsters infected and reinfected with Trypanosoma cruzi. Changes in genital organs have been described in human and in experimental chagasic infection. Genital dysfunctions in chronic chagasic patients affect ejaculation, libido and sexual potency, and testis biopsies may show arrested maturation of germ cells, oligozoospermia and azoospermia. Sixty-five male hamsters were inoculated and reinoculated with $2 \times 10^{3}$ trypomastigotes of T. cruzi VIC strain, and 22 non-infected animals constituted the control group. Animals were necropsied and fragments from testis, epididymis, seminal vesicle and bladder were collected and stained with hematoxylin-eosin. Peroxidase anti-peroxidase procedure was utilized to detect tissue parasitism. T. cruzi nests were found in testis, epididymis and seminal vesicle of these hamsters. Such parasitism plays a role in the origin of genital lesions observed in humans and laboratory animals during chronic chagasic infection.

Key words: hamsters - Trypanosoma cruzi - reinfection - testis - Chagas disease

Changes in genital organs associated with Trypanosoma cruzi infection have been described in humans (Chagas 1916a, b, Haddad et al. 1959, Jörg \& Oliva 1980, Lamano Carvalho et al. 1982a, b) and in laboratory animals (Vianna 1911, Ferreira \& Rossi 1973, Lamano Carvalho et al. 1991, Tavares et al. 1994, Lenzi et al. 1998, Herrera \& Urdaneta-Morales 2001). Chronic chagasic patients may present genital dysfunctions manifested as reduction of ejaculation, decreased libido, and lowered sexual potency (Haddad \& Raia 1969). Moreover, testicular biopsies in chagasic patients may show germ cell arrested maturation, with regressive changes ranging from the normospermic state to oligozoospermia and azoospermia (Lamano Carvalho et al. 1982a).

Experiments during acute chagasic infection in rodents have demonstrated diminution of seminal volume (Ferreira \& Oliveira 1965), atrophy of testis (Ferreira 1970, Ferreira \& Rossi 1973), reduced number of neurons in the juxtaprostatic pelvic ganglia (Ferreira 1970), and presence of $T$. cruzi in genital organs (Vianna 1911, Lamano Carvalho et al. 1991, Tavares et al. 1994, Lenzi et al. 1998, Herrera \& Urdaneta-Morales 2001). The local parasitism is possibly related with the origin of lesions observed in humans (Hartz \& Toledano 1954, Lamano Carvalho et al. 1982a, b) and in laboratory animals (Lamano Carvalho et al. 1991) during chronic chagasic infection.

The aim of this study was to investigate the presence of T. cruzi and evaluate the genitourinary changes in male hamsters infected and reinfected with this protozoan.

Financial support: Fapemig, Funepu, and Capes

${ }^{+}$Corresponding author. Fax: +55-34-3126640. E-mail: parasito_fmtm@mednet.com.br

Received 24 September 2002

Accepted 8 April 2003

\section{MATERIALS AND METHODS}

Animals - In this study, 87 non-isogenic male hamsters (Mesocricetus auratus), weighing about $108 \mathrm{~g}$, were manipulated in accordance to the bioethical recommendations for experiments utilizing laboratory animals (NIH Guide 1996, Pereira et al. 1998). Sixty-five hamsters were inoculated and reinoculated with $2 \times 10^{3}$ blood trypomastigotes of the T. cruzi VIC strain (Ramírez et al. 1994), while 22 non-infected animals constituted the normal control group.

Experimental design - Five infected animals and three normal controls were killed on the 15th, 30th, 45 th and 60 th days after the initial infection. On the 75 th day of the study, five out of the infected animals were randomly chosen as controls of one infection (group $K_{1}$ ) and preserved alive until the end of experiment. Five infected hamsters were killed (group $\operatorname{Inf}_{1}$ ), while all the other infected animals were reinoculated. This procedure was repeated on each 75 days, until the fourth reinoculation. On the 375 th day of the experiment, the 35 survivors: 20 infected controls (groups $\mathrm{K}_{1}, \mathrm{~K}_{2}, \mathrm{~K}_{3}$, and $\mathrm{K}_{4}$ ), 5 animals with 5 inoculations (group $\mathrm{Inf}_{5}$ ) and 10 non-infected controls were killed.

Each killed animal was submitted to a necropsy study and fragments from testis, epididymis, seminal vesicle and bladder were collected, fixed in $3.7 \%$ neutral buffered formalin, embedded in paraffin, sectioned at $4 \mu \mathrm{m}$, and stained with hematoxylin-eosin (HE). The peroxidase anti-peroxidase (PAP) procedure was utilized to detect $T$. cruzi in $4 \mu \mathrm{m}$ sections from the paraffin-embedded blocks. The sections were dewaxed in xylol, hydrated in graduated alcohols, treated with 3\% hydrogen peroxide in methanol for $10 \mathrm{~min}$, and heated in a microwave oven (two cycles) for $10 \mathrm{~min}$ with a solution of buffer citrate $10 \mathrm{mM}, \mathrm{pH} 6.0$, in Triton $0.05 \%$. After $20 \mathrm{~min}$, the sections were incubated with skimmed milk for $15 \mathrm{~min}$, washed with $\mathrm{pH} 7.2$ phosphate buffer saline (PBS) $0.01 \mathrm{M}$ and incubated for $22 \mathrm{~h}$ with rabbit anti-T. cruzi polyclonal antibodies, diluted with 
BSA 5\% in PBS at 1:6000. The kit labelled streptavidinbiotin-peroxidase (LSAB plus, K690, Dako) was used to detect the antibodies. The system was revealed using the 3,3 ' diaminobenzidine tetrahydrochloride solution, $5 \mathrm{mg} /$ $\mathrm{ml}$, and $0.75 \%$ hydrogen peroxide.

Statistical analysis - The Fisher's exact test was used to compare different groups of animals with the same number of infections, and the Spearman rank test to verify correlations. The level of significance assumed was $5 \%$ $(\mathrm{p}<0.05)$.

\section{RESULTS}

During the experiment, genitourinary histopathological changes did not occur in hamsters from the non-infected normal control group. In the acute phase of infection, discrete to moderate multifocal changes occurred with a high frequency in genitourinary organs of the infected hamsters.

Orchitis, germ cells arrested maturation, oligozoospermia and azoospermia were observed in the testis. In the epididymides, there was epididymitis, tubular contraction, absence of spermatozoa and cell desquamation. Interstitial inflammation and myositis were seen in the seminal vesicles, and myositis was also found in bladder.

In the chronic phase of infection, the histopathological aspect of genitourinary organs from the infected and reinfected animals (groups K and Inf) were similar to those observed during the acute infection (Table I), in addition to deposits of ceroid pigment in testis and epididymis, and calcification in the testis. The chronic changes were focal or diffuse, ranging in intensity from discrete to intense; more often, they appeared multifocal and discrete (Fig. 1). In the chronic phase, although without statistical significance, the testis and the epididymides from animals killed 30 days after reinoculations (groups Inf) presented higher frequency of changes when compared to hamsters killed on the 375th day of the experiment (groups $\mathrm{K})$. Similar data were not obtained from the study of the seminal vesicles and bladders; however, in the majority of cases the frequency of lesions in both organs was higher than in testis and epididymides, whether in animals from groups $\mathrm{K}$ or from groups Inf.

After reinfections, there was a progressive reduction in the frequency of lesions in the seminal vesicles. On the contrary, in hamsters from groups Inf and $\mathrm{K}$, a tendency to higher frequency of histopathological changes in testis and epididymides followed reinfections (Fig. 2); nevertheless, statistical significance was not observed through the Spearman correlation test.

In the acute and chronic phases of infection, the immunohistochemistry study (PAP) revealed T. cruzi amastigotes in the genitourinary organs from infected animals. On the first 30 days of the experiment, amastigotes were found in all the organs studied, mainly in testis and bladder (Table II).

In the chronic phase, T. cruzi was found in testis of animals from groups $\operatorname{Inf}_{3}(20 \%)$ and $\operatorname{Inf}_{4}(40 \%)$, and in testis $(40 \%)$ and seminal vesicles $(20 \%)$ of hamsters from group $\operatorname{Inf}_{2}$. Moreover, nests of parasites were present in $20 \%$ of bladders in animals from group $\mathrm{K}_{1}$ (Fig. 3 ).

\section{DISCUSSION}

Chagas (1916a, b) and Hartz and Toledano (1954) described the presence of T. cruzi in male genital organs during autopsy studies in chagasic patients, and similar parasitism has been demonstrated in rodents during the acute phase of infection (Vianna 1911, Lamano Carvalho et al. 1991, Lenzi et al. 1998, Herrera and Urdaneta-Morales 2001). However, in the chronic phase of chagasic infection, there is only one report of $T$. cruzi amastigotes in genitals of hamsters, predominantly in testis (CabrineSantos 2000).

Acute and chronic parasitism in those sites has been associated with inflammation, mainly orchitis and epididymitis, causing destruction and atrophy of germinative tubules, reduction or disappearance of spermatozoa, and may result in atrophy of genital organs (Vianna 1911, Lamano Carvalho et al. 1991, Cabrine-Santos 2000 ). Nevertheless, as similar alterations have been described without direct relation to tissue parasitism (Ferreira 1970, Ferreira \& Rossi 1973, Lamano Carvalho et al. 1982a, b), the histopathological changes in part could be due to late

TABLE I

Histopathological changes observed in genitourinary organs of hamsters chronically infected and reinfected with the Trypanosoma cruzi VIC strain, expressed in percentage

\begin{tabular}{|c|c|c|c|c|c|c|c|c|c|}
\hline \multirow[b]{2}{*}{ Histopathological changes } & \multicolumn{9}{|c|}{ Groups of infected hamsters } \\
\hline & $\begin{array}{r}\operatorname{Inf}_{1} \\
(\mathrm{n}=5)\end{array}$ & $\begin{array}{r}\mathrm{Inf}_{2} \\
(\mathrm{n}=5)\end{array}$ & $\begin{array}{r}\operatorname{Inf}_{3} \\
(\mathrm{n}=5)\end{array}$ & $\begin{array}{r}\operatorname{Inf}_{4} \\
(\mathrm{n}=5)\end{array}$ & $\begin{array}{r}\operatorname{Inf}_{5} \\
(\mathrm{n}=5)\end{array}$ & $\begin{array}{r}\mathrm{K}_{1} \\
(\mathrm{n}=5)\end{array}$ & $\begin{array}{r}\mathrm{K}_{2} \\
(\mathrm{n}=5)\end{array}$ & $\begin{array}{r}\mathrm{K}_{3} \\
(\mathrm{n}=5)\end{array}$ & $\begin{array}{r}\mathrm{K}_{4} \\
(\mathrm{n}=5)\end{array}$ \\
\hline Orchitis & 0 & 60 & 60 & 100 & 20 & 40 & 0 & 40 & 40 \\
\hline Germ cells arrested maturation & 20 & 0 & 80 & 80 & 40 & 20 & 20 & 40 & 20 \\
\hline Oligozoospermia/Azoospermia & 20 & 60 & 80 & 80 & 20 & 20 & 0 & 20 & 0 \\
\hline Epididymitis & 40 & 80 & 60 & 60 & 60 & 40 & 40 & 80 & 40 \\
\hline Tubular contraction & 20 & 60 & 80 & 20 & 20 & 20 & 40 & 0 & 0 \\
\hline No spermatozoa in epididymis & 0 & 60 & 80 & 60 & 20 & 0 & 20 & 0 & 0 \\
\hline Inflammation in seminal vesicle & 80 & 100 & 80 & 40 & 20 & 40 & 80 & 80 & 80 \\
\hline Miositis in seminal vesicle & 40 & 40 & 20 & 0 & 0 & 20 & 0 & 0 & 40 \\
\hline Miositis in bladder & 100 & 50 & 80 & 100 & 80 & 80 & 80 & 80 & 80 \\
\hline
\end{tabular}

n: number of animals; Inf: animals inoculated or reinoculated and killed after 30 days; K: animals inoculated or reinoculated and killed on the 375 th day of the experiment. In each group, the subscript number indicates the number of $T$. cruzi inoculations. 
effects of the acute chagasic infection, including destruction of neurons in the juxtaprostatic pelvic ganglia (Ferreira 1970) and reduced testosterone levels following disturbances in the hypothalamic-hypophyseal-testicular axis (Tavares et al. 1994).
In this study, the presence of amastigotes was well demonstrated through the PAP procedure, during both phases of chagasic infection, and tissue parasitism was invariably associated with inflammation and its sequels in all the genitourinary sites examined. Although the his-

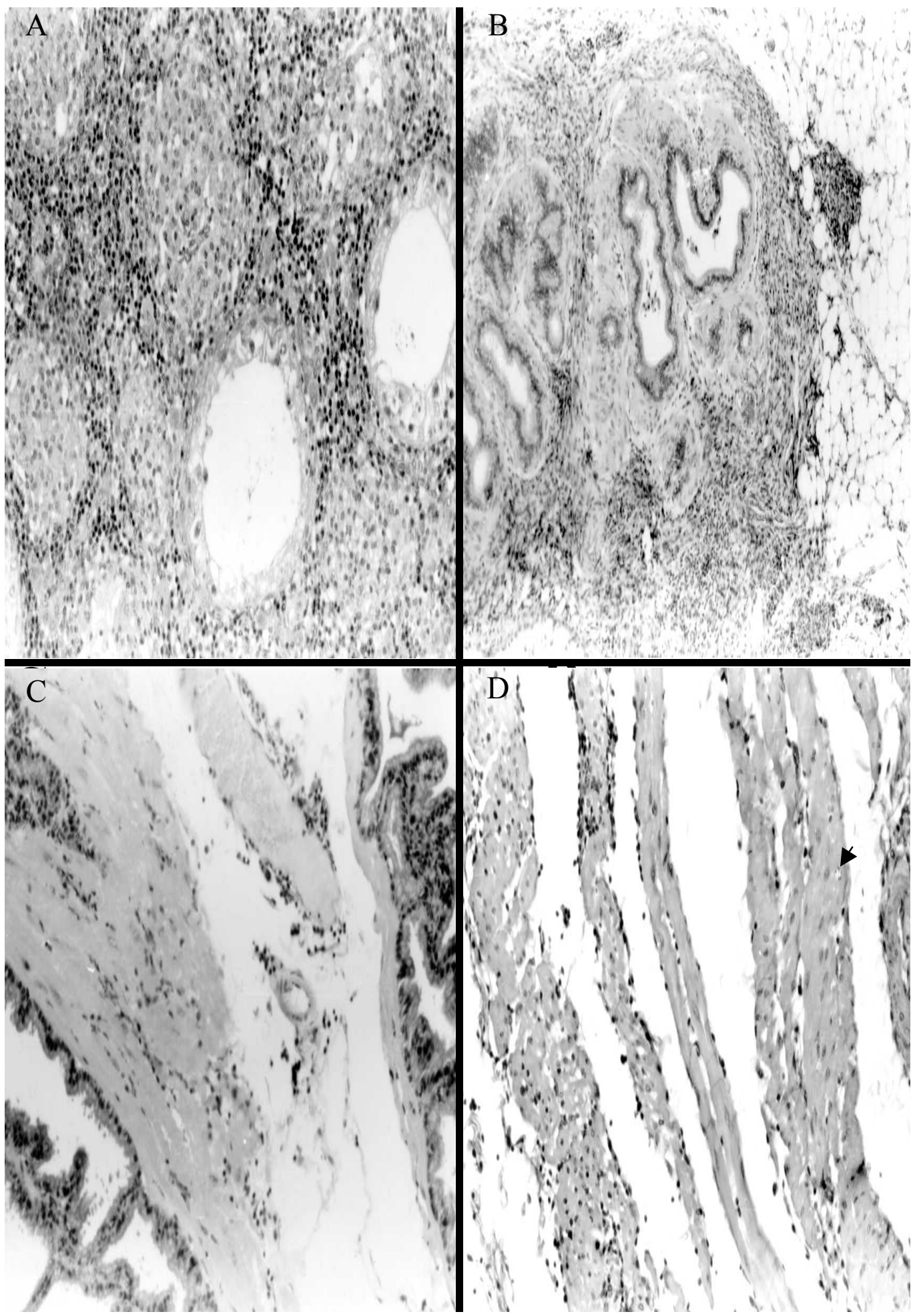

Fig.1: photomicrography from testis (A; x 400), epididymis (B; x 200), seminal vesicle (C; x 400) and bladder (D; x 400) of hamsters infected with Trypanosoma cruzi, showing chronic inflammation of variable intensity, and a nest of amastigotes (arrow) in bladder (Hematoxylin-eosin). 
topathological change in juxtaprostatic pelvic ganglia was similar to that previously described (Ferreira 1970), its systematized evaluation was not performed.

The intensity of histopathological changes found in testis and epididymides of reinfected animals from the groups Inf and $\mathrm{K}$ was different. This could be due to differences in tissue parasitism, which was more conspicuous in hamsters from groups Inf during the chronic phase of the infection. As the infected animals from groups $\mathrm{K}$ were kept alive for about one year, the lesions initially caused by $T$. cruzi infection could have regenerated during this span of time. It is known that if spermatogonia are well preserved, the germinative epithelium may have regenerated (Oakberg 1957, Ferreira \& Rossi 1973). Since we found normal type A spermatogonia, even in the damaged tubules (data not shown), this regenerative phenomenon possibly occurred in the animals of our study.
The frequency of inflammatory changes was higher in seminal vesicles and bladder than in testis and epididymides, both in groups $\mathrm{K}$ and Inf of the infected hamsters. This difference may be due to the abundance of smooth muscle in the first two sites, since muscular tissue constitutes one of the preferential targets for T. cruzi infection (Bice \& Zeledon 1970, Andrade \& Andrade 1979).

The higher intensity of the inflammatory lesions observed in testis and epididymides following the number of reinfections may indicate that reinfections are an aggravating factor of tissue lesions in hamsters, as suggested by Cabrine-Santos et al. (2001). Nevertheless, a major concern is related to the route for inoculations of trypomastigotes in the inferior abdominal quadrant of the animals, which could favor the injection of parasites in the close vicinity of genitourinary organs.
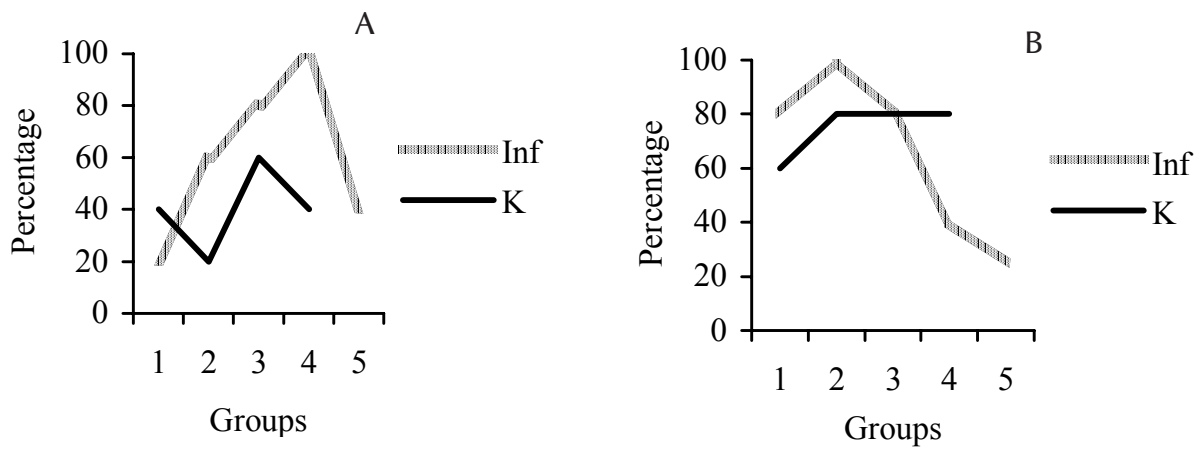

$\mathrm{C}$
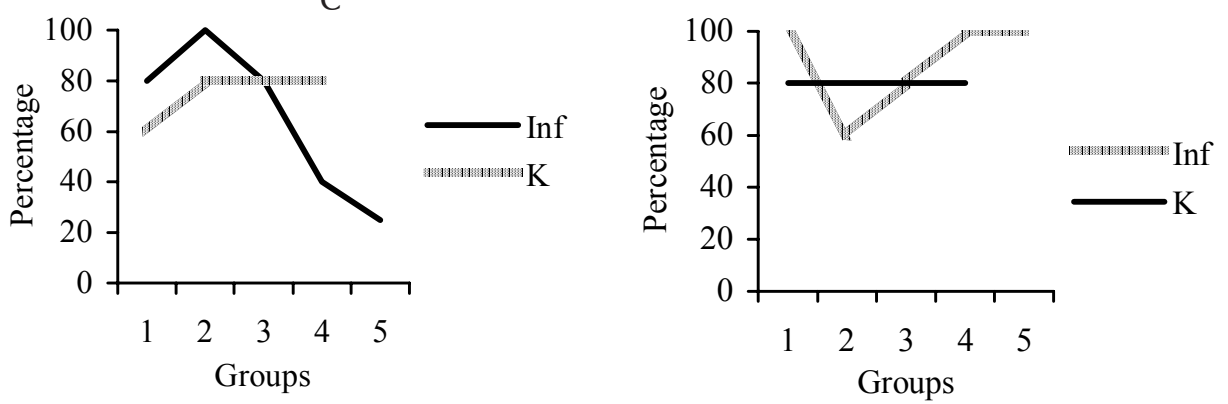

Fig. 2: general histopathological changes observed in genitourinary organs of hamsters infected and reinfected with the Trypanosoma cruzi VIC strain. A: testis; B: seminal vesicle; C: epididymis; D: bladder; Inf: animals inoculated or reinoculated and killed after 30 days; K: animals inoculated or reinoculated and killed on the 375th day of the experiment. In each group, the subscript number indicates the number of T. cruzi inoculations

TABLE II

Tissue parasitism observed in genitourinary organs of hamsters acutely infected with the Trypanosoma cruzi VIC strain, expressed in percentage

\begin{tabular}{lcccr}
\hline & \multicolumn{4}{c}{ Days of infection } \\
\cline { 2 - 5 } Organs affected $^{a / b}$ & 15 & 30 & 45 & 60 \\
\hline Testis $_{\text {Epididymis }}$ & $2 / 5(40)$ & $4 / 5(80)$ & $2 / 5(40)$ & $3 / 5(60)$ \\
Seminal vesicle & $1 / 5(20)$ & $2 / 4(50)$ & 0 & $1 / 5(20)$ \\
Bladder & $1 / 4(25)$ & $3 / 4(75)$ & 0 & 0 \\
Total & $5 / 5(100)$ & $9 / 18(50)$ & 0 & 0 \\
\hline
\end{tabular}

$a / b$ : number of animals showing tecidual parasitism/total number of animals 


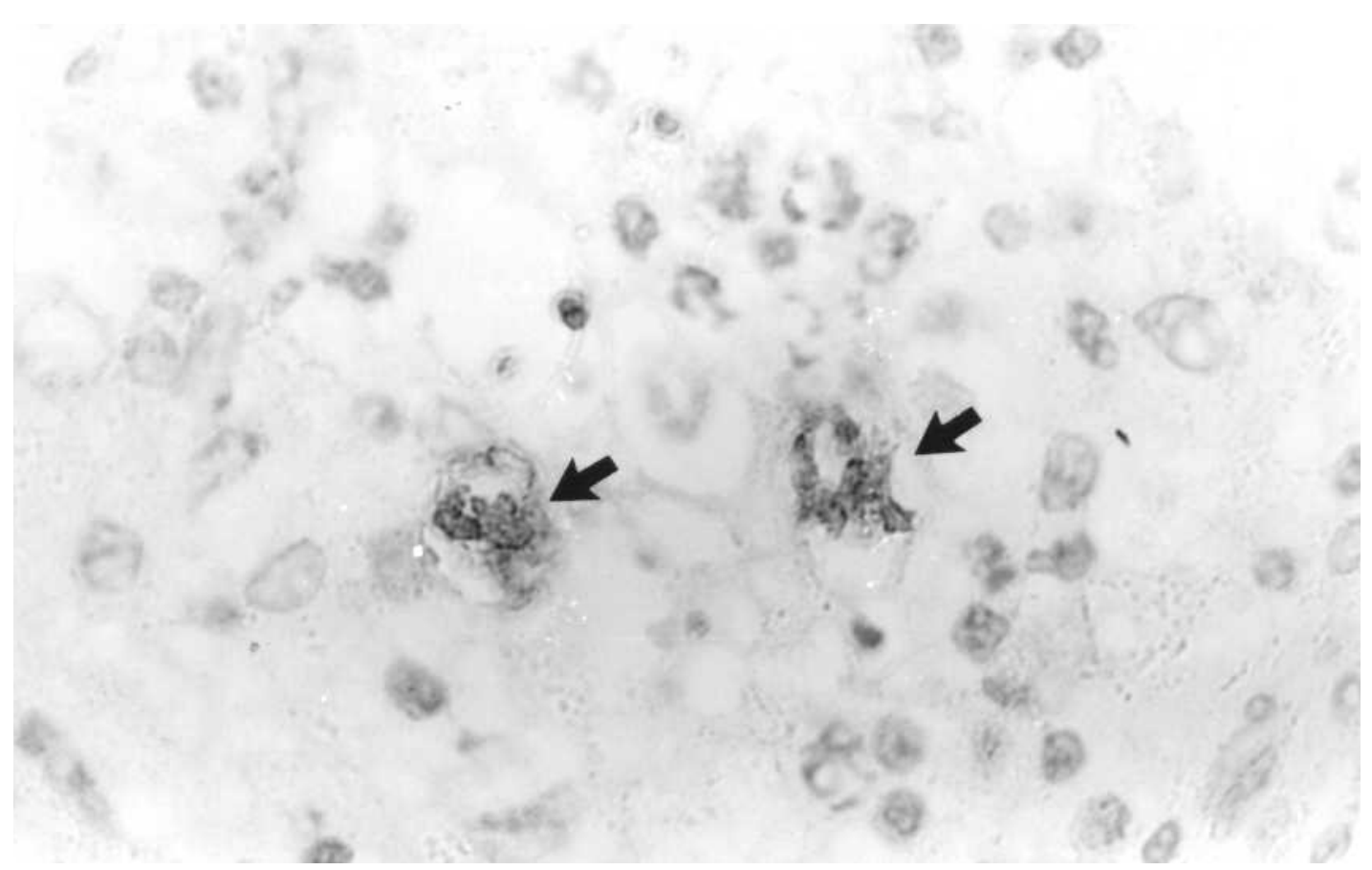

Fig. 3: photomicrography from testis of hamsters infected with Trypanosoma cruzi, showing amastigotes nests (arrows) (Peroxidase antiperoxidase; $x$ 400).

Moreover, preliminary results from a recent experiment in our Laboratory, utilizing a dorsal subcutaneous route of infection, showed a positive anti-T. cruzi PAP procedure in sections of pancreas and negative in samples of genital organs from eight male hamsters infected with the same T. cruzi VIC strain (Santos 2002).

Therefore, a simple extrapolation about the genital findings from an experimental chagasic infection to the naturally acquired human Chagas disease seems not entirely appropriate. More often, male small rodents are experimentally infected through intraperitoneal injections containing $10^{5}$ to $5 \times 10^{5}$ virulent trypomastigotes (Ferreira 1970, Ferreira \& Rossi 1973, Lamano Carvalho et al. 1991, Tavares et al. 1994, Lenzi et al. 1998, Cabrine-Santos 2000). Otherwise, rodent genital infection is obtained through local inoculations with $2 \times 10^{2}$ to $1.2 \times 10^{5}$ parasites (Herrera \& Urdaneta-Morales 2001).

In conclusion, our data indicate that genitourinary structures of male hamsters may be acutely and chronically infected with $T$. cruzi. The parasitism in these sites may play a role in the origin and development of the histopathological changes observed in sections of those organs from infected and reinfected hamsters.

\section{REFERENCES}

Andrade ZA, Andrade SG 1979. Patologia. In Z Brener, ZA Andrade (eds), Trypanosoma cruzi e Doença de Chagas, Guanabara-Koogan, Rio de Janeiro, p. 199-248.

Bice DE, Zeledon R 1970. Comparison of infectivity of strains of Trypanosoma cruzi (Chagas, 1909). J Parasitol 56: 663670.

Cabrine-Santos, M 2000. Estudo da Fase Crônica da Infecção e Reinfecção por Trypanosoma cruzi no Hamster: Avaliação e Caracterização da Cepa VIC por Métodos Parasitológicos,
Imunohistoquímicos e de Biologia Molecular, MSc Thesis, Faculdade de Medicina do Triângulo Mineiro, Uberaba, 144 pp.

Cabrine-Santos M, Lages-Silva E, Chapadeiro E, Ramírez LE 2001. Trypanosoma cruzi: characterization of reinfection and search for tissue tropism in hamsters (Mesocricetus auratus). Exp Parasitol 99: 160-167.

Chagas C 1916a. Processos patojênicos da tripanozomiase americana. Mem Inst Oswaldo Cruz 8: 5-35.

Chagas C 1916b. Trypanosomiase americana. Forma aguda da moléstia. Mem Inst Oswaldo Cruz 8: 37-65.

Ferreira AL 1970. Patogênese das lesões testiculares e epididimárias em cobaios infectados experimentalmente com Trypanosoma cruzi. Rev Inst Med Trop São Paulo 12: 69-87.

Ferreira AL, Oliveira JSM 1965. Volume do sêmen obtido por eletro-ejaculação de ratos chagásicos (inoculados experimentalmente). Rev Inst Med Trop São Paulo 7: 127-130.

Ferreira AL, Rossi MA 1973. Pathology of the testis and epididymis in the late phase of experimental Chagas' disease. Am J Trop Med Hyg 22: 699-704.

Haddad J, Raia A 1969. Alterações sexuais após o tratamento cirúrgico do megacólon congênito e adquirido. Rev Assoc Med Brasil 15: 509-512.

Haddad J, Raia A, Erhart EA 1959. Estudo das atividades sexuais nos pacientes portadores de megacólon, antes e após a retossigmoidectomia abdominoperineal. Rev Paul Med 55: 343-354.

Hartz PH, Toledano D 1954. Specific orchitis in Chagas' disease. Doc Med Geograph Trop 6: 124-130.

Herrera L, Urdaneta-Morales S 2001. Experimental transmission of Trypanosoma cruzi through the genitalia of albino mice. Mem Inst Oswaldo Cruz 96: 713-717.

Jörg ME, Oliva R 1980. Presencia de tripomastigotes en sangre menstrual de mujeres con tripanosomiasis cruzi. Rev Arg Parasitol 1: 28-30. 
Lamano Carvalho TL, Ferreira AL, Sahao MA 1982a. Alterações do testículo humano na moléstia de Chagas. I - Avaliação da cinética da espermatogênese. Rev Inst Med Trop São Paulo 24: 205-213.

Lamano Carvalho TL, Ferreira AL, Sahao MA 1982b. Alterações do testículo humano na moléstia de Chagas. II - Estudo morfométrico do tecido intersticial. Rev Inst Med Trop São Paulo 24: 214-221.

Lamano Carvalho TL, Ribeiro RD, Lopes RA 1991. The male reproductive organs in experimental Chagas' disease. Exp Pathol 41: 203-214.

Lenzi HL, Castelo-Branco MTL, Pelajo-Machado M, Oliveira DN, Gattass CR 1998. Trypanosoma cruzi: compromise of reproductive system in acute murine infection. Acta Trop 71: 117-129.

NIH Guide 1996. Revised Guide for the Care and Use of Laboratory Animals, National Academy Press, Washington.

Oakberg EF 1957. Gamma-ray sensitivy of spermatogonia of the mouse. J Exp Zool 134: 343-356.
Pereira CEM, Silva JDM, Romeiro VR 1998. Aspectos da experimentação animal. Acta Cir Bras 13: 123-128.

Ramírez LE, Lages-Silva E, Soares Junior JM, Chapadeiro E 1994. The hamster (Mesocricetus auratus) as experimental model in Chagas' disease: parasitological and histopathological studies in acute and chronic phases of Trypanosoma cruzi infection. Rev Soc Bras Med Trop 27: 163-169.

Santos VM 2002. Estudo Parasitológico, Funcional e Morfológico do Pâncreas de Hamsters Infectados e Reinfectados com Trypanosoma cruzi, PhD Thesis, Faculdade de Medicina do Triângulo Mineiro, Uberaba, $128 \mathrm{pp}$.

Tavares MCH, Carraro AA, Vianna Favaretto AL, Petenusci SO, Lopes RA, Ribeiro RD, Lamano Carvalho TL 1994. The male reproductive organs in experimental Chagas' disease. Exp Toxic Pathol 46: 243-246.

Vianna G 1911. Contribuição para o estudo da anatomia patológica da moléstia de Chagas. Mem Inst Oswaldo Cruz 3: 276-294. 